\title{
Crystal Structure and Characterization of the Dinuclear Cd(II) Complex $\left[\mathrm{Cd}\left(\mathrm{H}_{2} \mathrm{O}\right)_{2}\left(o-\mathrm{HOC}_{6} \mathrm{H}_{4} \mathrm{COO}\right)_{2}\right]_{2}$
}

\author{
Fangfang Jian ${ }^{1, *}$, Hailian Xiao ${ }^{1}$, Pingping Sun ${ }^{1}$ and Pusu Zhao ${ }^{2}$
}

1 New Materials \& Function Coordination Chemistry Laboratory, Qingdao University of Science and Technology, Qingdao, 266042, P. R. China.

2 Materials Chemistry Laboratory, Nanjing University of Science and Technology, Nanjing, 210094, P. R. China.

* Author to whom correspondence should be addressed. E-mail: ffj2003@163169.net; Tel. (+86)-5324023606, Fax. (+86)-532-4023606

Received: 18 June 2004 / Accepted: 21 July 2004 / Published: 30 September 2004

Abstract: The structure of a new binuclear cadmium (II) complex, $\left[\mathrm{Cd}\left(\mathrm{H}_{2} \mathrm{O}\right)_{2}(\mathrm{Sal})_{2}\right]_{2}(\mathrm{Sal}$ = salicylate), has been determined by X-ray crystallography. It was also characterized by elemental analysis, its IR spectrum and thermogravimetric-differential scanning calorimetry (TG-DSC). It crystallizes in the monoclinic system, space group $\mathrm{P} 2{ }_{1} / \mathrm{c}$, with lattice parameters $a=15.742(3) \AA, b=12.451(3) \AA, c=7.7225(15) \AA, \beta=96.07(3)^{\circ}$ and $\mathrm{Z}=4$. Two cadmium (II) ions are bridged by two $\mu_{2}$-carboxy oxygen atoms. Each cadmium atom lies in a distorted capped octahedron coordination geometry. The thermal gravimetry (TG) data indicate that there are four discrete decomposition steps with two endothermic peaks and one exothermic peak. The final thermal decomposition product is CdO.

Keywords: Salicylate, cadmium (II) complex, single crystal structure, TG-DSC. 


\section{Introduction}

$\mathrm{Cd}^{2+}$ ions have been found to induce various pathological conditions, such as cardiovascular diseases [1], hypertension and cancer [2]. Cadmium can replace the zinc of superoxide dismutase (SOD) and this results in a drop in the biological activity of SOD [3]. In addition, cadmium has some stress-causing activity towards enzymes inolved in the tolerance mechanisms of crops [4]. Cadmium(II), being a $d^{10}$ ion, provides few spectroscopic signatures for structure monitoring, however, the structure of the cadmium complex could be elucidated by X-ray crystallography. In this paper, we report the synthesis and crystal structure of the title compound. Its elemental analysis, FT-IR and thermal analysis have also been investigated.

\section{Results and Discussion}

\section{Crystal Structure Study of the Title Compound}

The molecular structure of the title compound is illustrated in Figure 1. Figure 2 shows a perspective view of the crystal packing in the unit cell. The crystal structure consists of dimeric molecules. The complex has an inversion centre located at the middle of the dimer. Each cadmium atom is located in the centre of a capped octahedron and is coordinated by seven $\mathrm{O}$ atoms, five of which $[\mathrm{O}(2), \mathrm{O}(3), \mathrm{O}(4), \mathrm{O}(5)$ and $\mathrm{O}(2 \mathrm{~A})]$ are from three different carboxylate groups and two $[\mathrm{O}(6)$ and $\mathrm{O}(7)]$ from two independent water molecules. For the $\mathrm{Cd}(1)$-center, the carboxy $\mathrm{O}(4), \mathrm{O}(5)$ and two bridged oxygen atoms $\mathrm{O}(2), \mathrm{O}(2 \mathrm{~A})$ are all located at equatorial positions, the two coordinated water oxygen atoms $\mathrm{O}(6)$ and $\mathrm{O}(7)$ are located respectively at two axial sites. The another oxygen atom $\mathrm{O}(3)$ is the capped atom. Two carboxy oxygen atoms $[\mathrm{O}(2)$ and $\mathrm{O}(2 \mathrm{~A})]$ acting as the bridges connect $\mathrm{Cd}(1)$ and $\mathrm{Cd}(1 \mathrm{~A})$. The $\mathrm{Cd}-\mathrm{O}$ distances (2.275-2.534 $\AA$ ) in the equatorial and capped position $[\mathrm{O}(2), \mathrm{O}(3), \mathrm{O}(4), \mathrm{O}(5)$ and $\mathrm{O}(2 \mathrm{~A})]$ are quite similar to normal Cd-OCO distances (2.251-2.879 $\AA)$ [5]. However, both of these carboxylates are bound asymmetrically with one $\mathrm{Cd}-\mathrm{O}$ bond length somewhat longer than the other [6]. The Cd-Ow bond distances [2.235(3) and 2.294(3) $\AA$ ] in the apical positions fall within the normal range [7, 8]. The long $\mathrm{Cd} \cdots \mathrm{Cd}$ distance $(3.8099 \AA)$ indicates that there is no interaction between the two metal atoms [9]. The o-hydroxybenzoic groups $1[\mathrm{C}(1) \sim \mathrm{C}(7)$ and $\mathrm{O}(1) \sim \mathrm{O}(3)]$ and $2[\mathrm{C}(8) \sim \mathrm{C}(14), \mathrm{O}(4), \mathrm{O}(5)$ and $\mathrm{O}(8)]$ are all fairly planar and the mean deviations from the best plane are $0.071 \AA$ for 1 and $0.062 \AA$ for 2 , respectively. The two $\mathrm{Cd}(1)$ and $\mathrm{Cd}(1 \mathrm{~A}) \operatorname{metal}$ atoms are also planar with the oxygen atoms $\mathrm{O}(2), \mathrm{O}(3), \mathrm{O}(2 \mathrm{~A})$ and $\mathrm{O}(3 \mathrm{~A})$, the largest deviation being $0.013 \AA$. The dihedral angles between the planes of $\mathrm{Cd}_{2} \mathrm{O}_{4}$ moieties and the $o$-hydroxybenzoic groups 1 and 2 are $15.21^{\circ}$ and $23.01^{\circ}$, respectively. The dihedral angle between the two $o$-hydroxybenzoic groups is $37.72^{\circ}$. There are some intermolecular hydrogen bonds and $\pi$ - $\pi$ stacking interactions between the molecules in the crystal lattice. The hydrogen bond distances are presented in Table 2. The two coordinated water molecules $\mathrm{O}(6 \mathrm{w})$ and $\mathrm{O}(7 \mathrm{w})$ form a strong hydrogen bond with the hydroxyl oxygen $\mathrm{O}(1)$ and carboxyl oxygen $\mathrm{O}(5)$ atoms. The donor and acceptor distances are $\mathrm{O}(6) \cdots \mathrm{O}(1) 2.8335 \AA$ 
(symmetry code: $-\mathrm{x},-1 / 2+\mathrm{y}, 1 / 2-\mathrm{z}$ ), $\mathrm{O}(6) \cdots \mathrm{O}(5) 3.0104 \AA$ (symmetry code: $\mathrm{x}, 3 / 2-\mathrm{y}, 1 / 2+\mathrm{z}$ ), $\mathrm{O}(7) \cdots \mathrm{O}(1) 2.8687 \AA$ (symmetry code: $-\mathrm{x},-1 / 2+\mathrm{y},-1 / 2-\mathrm{z})$ and $\mathrm{O}(6) \cdots \mathrm{O}(1) 2.7066 \AA$ (symmetry code: $\mathrm{x}$, $3 / 2-y,-1 / 2+z)$, respectively. There are two types of strong $\pi-\pi$ stacking interactions: phenyl ring $1(X$, $Y, Z)$-phenyl ring $1(X, 3 / 2-Y, 1 / 2+Z)$ and phenyl ring $2(X, Y, Z)$-phenyl ring $2(X, 3 / 2-Y,-1 / 2+Z)$. The center-to-center distances are 3.904 and $3.993 \AA$, respectively. The shortest interplanar distances mentioned above are $3.651 \AA$ and $3.612 \AA$, respectively. It is obvious that they all contribute to the slightly stronger $\pi-\pi$ stacking interaction $[10,11]$. In the solid state, these hydrogen bond and intermolecular interactions stabilize the structure.

Figure 1: Molecular structure for $\left[\mathrm{Cd}\left(\mathrm{H}_{2} \mathrm{O}\right)_{2}\left(o-\mathrm{HOC}_{6} \mathrm{H}_{4} \mathrm{COO}\right)_{2}\right]_{2}$.

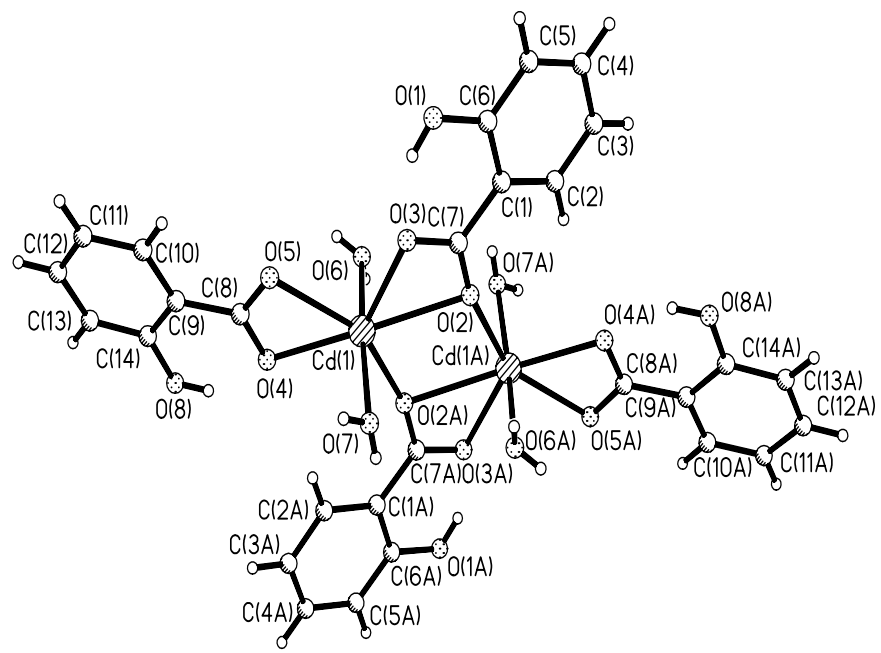

Figure 2: Packing diagram of the unit cell along the $\mathrm{b}$ axis.

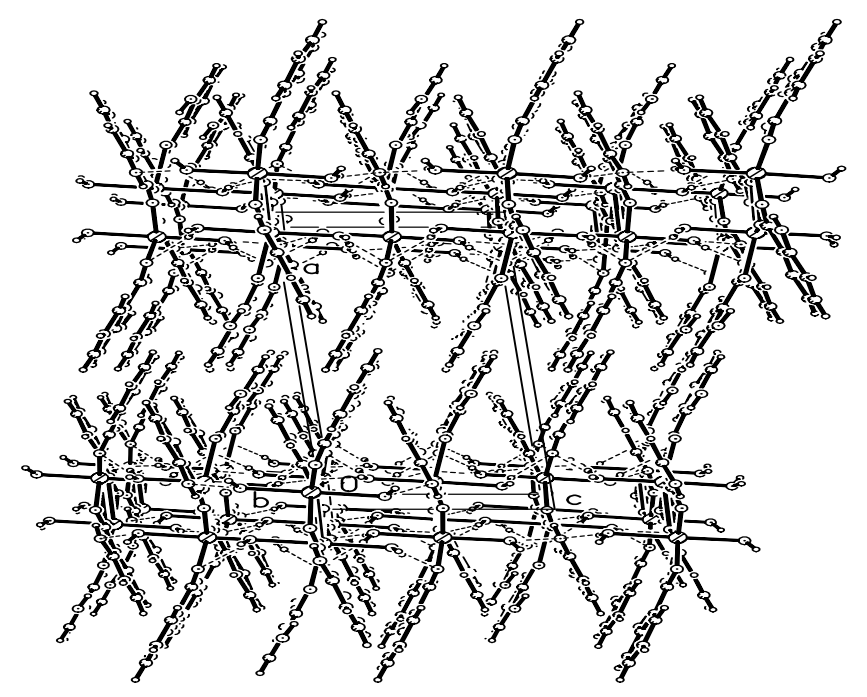


Table 2: Intermolecular interaction distances $(\AA)$ of the title compound

\begin{tabular}{|c|c|c|c|c|c|}
\hline D $\quad \mathbf{H} \quad \mathbf{A}$ & symm & D-H & $\mathrm{H} \cdots \mathrm{A}$ & D $\cdots \mathbf{A}$ & D-HoA \\
\hline $\mathrm{O}(1)-\mathrm{H}(1 \mathrm{~A}) \cdots \mathrm{O}(3)$ & 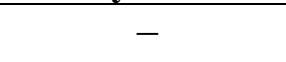 & 0.8200 & 1.7917 & 2.5222 & 147.54 \\
\hline $\mathrm{O}(8)-\mathrm{H}(2 \mathrm{~B}) \cdots \mathrm{O}(4)$ & - & 0.8446 & 1.8319 & 2.5741 & 145.71 \\
\hline$\partial($ & 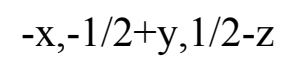 & 0 & 2.0476 & 5 & 160.42 \\
\hline $\mathrm{O}(6)-\mathrm{H}(6 \mathrm{~B}) \cdots \mathrm{O}(5)$ & $\mathrm{x}, 3 / 2-\mathrm{y}, 1 / 2+\mathrm{z}$ & 0.7065 & 2.3152 & 3.0104 & 168.2 \\
\hline $\mathrm{O}(7)-\mathrm{H}(7 \mathrm{~A}) \cdots \mathrm{O}(5)$ & $\mathrm{x}, 3 / 2-\mathrm{y},-1 / 2-$ & 0.8200 & 1.9050 & 2.7066 & 165.44 \\
\hline $\mathrm{O}(7)-\mathrm{H}(7 \mathrm{~B}) \cdots \mathrm{O}(1)$ & $-x,-1 / 2+y,-1 / 2-z$ & 0.7211 & 2.2117 & 2.8687 & 152.0 \\
\hline
\end{tabular}

\section{IR Spectra}

In the IR spectra, the bands around $3418 \sim 3548 \mathrm{~cm}^{-1}$ can be attributed to O-H stretching modes, which are consistent with the presence of water in the crystal [12]. The characteristic absorption bands at 1617 and $1637 \mathrm{~cm}^{-1}$ are the salicylate antisymmetric carboxyl vibrations, while the symmetric carboxyl stretching frequency occurs at $1429 \mathrm{~cm}^{-1}[13,14]$.

\section{Thermal Analysis}

The TG/DSC curves of the title compound are presented in Figure 3. In this figure we can see that there are four discrete weight loss steps and that the decomposition events mainly take place at $66.9^{\circ} \mathrm{C}$, $172.3^{\circ} \mathrm{C}$ and $512.5^{\circ} \mathrm{C}$, with two heat-absorption peaks and one heat-liberation peak, respectively. On the base of weight changes, the first endothermic weight loss process $(8.90 \%)$ corresponds to the loss of two water molecules (found $8.90 \%$ calc. $8.52 \%$ ); the second weight loss event may be related to the loss of one phenol $(\mathrm{PhOH})$ molecule with the breakage of C-C bonds (found: $22.43 \%$, calc. 22.00 $\%$ ), an exothermic phenomenon. The weight loss of $3.58 \%$ from $240^{\circ} \mathrm{C}$ to $370^{\circ} \mathrm{C}$ is attributed to the loss of one oxygen atom (found: $3.58 \%$, calc. $3.79 \%$ ). There is a broad endothermic peak at $512.5^{\circ} \mathrm{C}$ and $c a .33 .93 \%$ weight loss in the TG curve between $380 \sim 540^{\circ} \mathrm{C}$, which is attributed to the loss of the phenol groups, while the residual weight of $31.16 \%$ suggests that the residue may be $\mathrm{CdO}$ (found $31.16 \%$ calcd. $30.38 \%$ ). In the temperature range of $540 \sim 730^{\circ} \mathrm{C}$, there is about an $18.21 \%$ weight loss. From this weight loss we can suggest that the corresponding transition process may be attributed to the sublimation of part of the $\mathrm{CdO}$. 
Figure 3: TG/DSC curves of the title compound

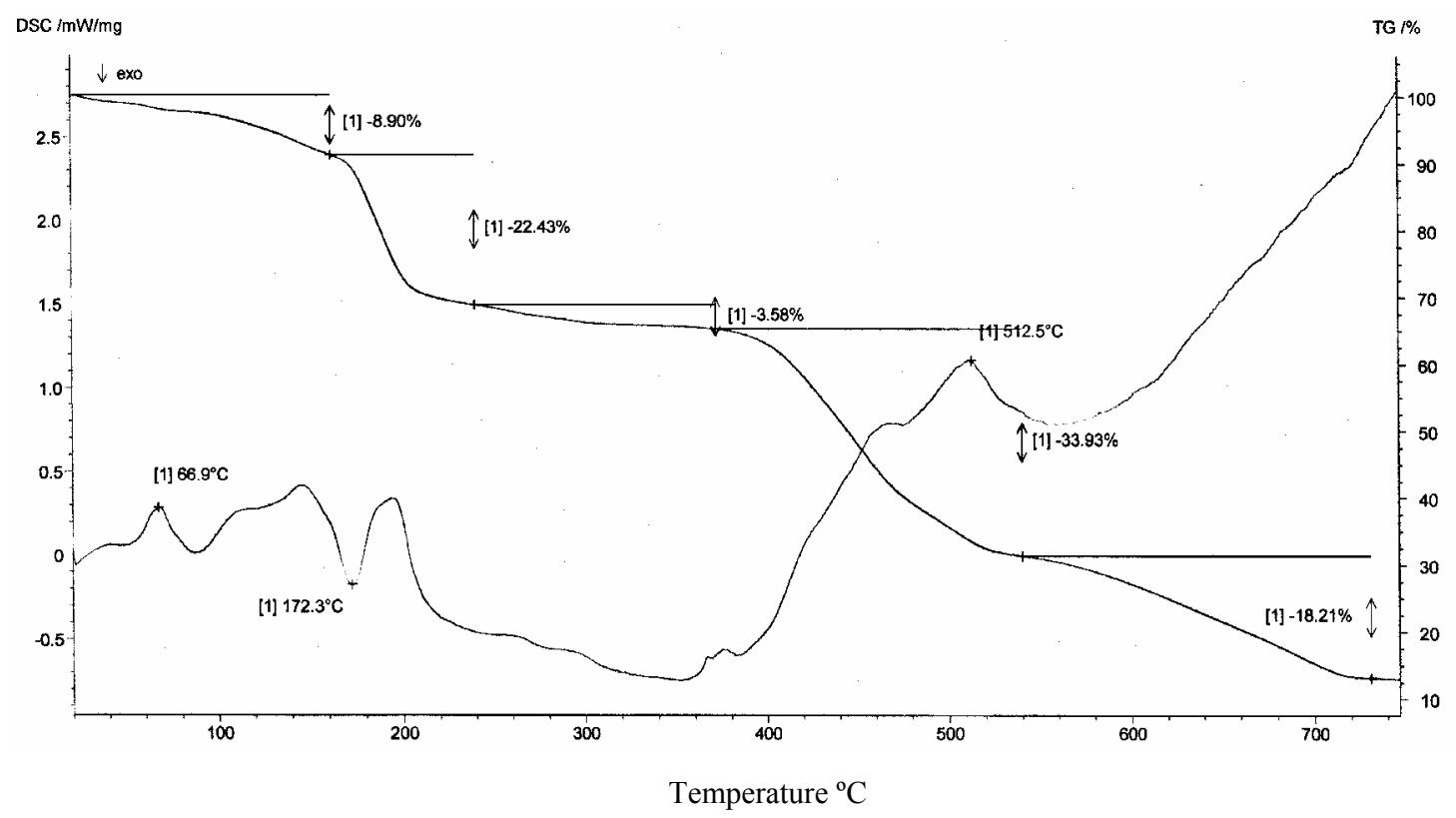

\section{Acknowledgements}

The authors would like to thank Natural Science Foundation of Shandong Province (No.Y2002B06) and Science Research Foundation of Qingdao University of Science and Technology (No. 03Z08).

\section{Experimental}

\section{General}

All chemicals were of analytical reagent grade and used directly without further purification. Elemental analyses were measured with a Perkin-Elmer 1400C analyzer. Infrared spectra were recorded in the $4000-400 \mathrm{~cm}^{-1}$ range on a Nicolet 170SX spectrometer using pressed $\mathrm{KBr}$ plates. Thermal gravity (TG) and differential scanning calorimetry (DSC) curves were recorded simultaneously for samples of $c a .10 \mathrm{mg}$ under a nitrogen atmosphere $(150 \mathrm{~mL} / \mathrm{min})$ on an SDT 2980 instrument at a heating rate of $10^{\circ} \mathrm{C} / \mathrm{min}$.

Preparation of $\left[\mathrm{Cd}\left(\mathrm{H}_{2} \mathrm{O}\right)_{2}\left(\mathrm{O}-\mathrm{HOC}_{6} \mathrm{H}_{4} \mathrm{COO}\right)_{2}\right]_{2}$

An aqueous solution $(15 \mathrm{~mL})$ of sodium salicylate $(0.3 \mathrm{~g}, 2.1 \mathrm{mmol})$ and an aqueous solution $(10 \mathrm{~mL})$ of cadmium(II) sulfate hexahydrate $(0.3 \mathrm{~g}, 1.0 \mathrm{mmol})$ were mixed with stirring, then the mixture was sealed in a $50 \mathrm{~mL}$ stainless-steel reactor equipped with a Teflon liner and heated at $110^{\circ} \mathrm{C}$ for $72 \mathrm{~h}$ to give colorless crystals of the title complex upon cooling The $\mathrm{C}, \mathrm{H}$ and $\mathrm{N}$ contents were determined by elemental analysis: Calcd.(\%) for $\left[\mathrm{Cd}\left(\mathrm{H}_{2} \mathrm{O}\right)_{2}\left(\mathrm{HOC}_{6} \mathrm{H}_{4} \mathrm{COO}\right)_{2}\right]_{2}$ : C 39.75, H 3.31; Found.(\%) C 39.72, H 3.05 . 


\section{X-Ray Diffraction Analysis [15]}

A summary of the key crystallographic information is given in Table 1. The selected crystal of $\left[\mathrm{Cd}\left(\mathrm{H}_{2} \mathrm{O}\right)_{2}\left(o-\mathrm{HOC}_{6} \mathrm{H}_{4} \mathrm{COO}\right)_{2}\right]_{2}$ was mounted on an Rigaku Raxis-IV diffractometer using Mo-Ka radiation $(\lambda=0.71073 \AA, T=293 \mathrm{~K})$ with a graphite monochromator. Intensities were corrected for Lorentz and polarization effects and empirical absorption, and the data reduction using the SADABS program [16]. The structure was solved by the direct methods and all the non-hydrogen atoms were refined on $F^{2}$ anistropically by the full-matrix least squares method [17]. The hydrogen atom positions were fixed geometrically at calculated distances and allowed to ride on the parent carbon atoms. The molecular graphics were plotted using SHELXTL [17]. Atomic scattering factors and anomalous dispersion corrections were taken from International Tables for X-ray Crystallography [18].

Table 1: Crystal data and structure refinement for the title compound

\begin{tabular}{|l|l|}
\hline Empirical formula & $\mathrm{C}_{14} \mathrm{H}_{14} \mathrm{CdO}_{8}$ \\
Formula weight & 422.65 \\
Temperature & $293(2) \mathrm{K}$ \\
Wavelength & $0.71073 \AA$ \\
Crystal system, space group & Monoclinic, $P 2_{1} / c$ \\
Unit cell dimensions & $a=15.742(3) \AA$ \\
& $b=12.451(3) \AA \quad \beta=96.07(3)^{\circ}$ \\
Volume & $c=7.7225(15) \AA$ \\
$Z$, Calculated density & $1505.1(5) \AA$ \\
Absorption coefficient & $4,1.865 \mathrm{Mg} / \mathrm{m}^{3}$ \\
$F(000)$ & $1.491 \mathrm{~mm}^{-1}$ \\
Crystal size & 840 \\
Theta range for data collection & $0.30 \times 0.20 \times 0.18 \mathrm{~mm}$ \\
Limiting indices & 1.30 to $27.58 \mathrm{deg}$ \\
Reflections collected / unique & $-20 \leq \mathrm{h} \leq 20,-16 \leq \mathrm{k} \leq 16,0 \leq 1 \leq 10$ \\
Completeness to theta $=27.43$ & $5198 / 3024[\mathrm{R}($ int $)=0.0322]$ \\
Refinement method & $86.9 \%$ \\
Data / restraints / parameters & Full-matrix least-squares on $F^{2}$ \\
Goodness-of-fit on $F^{2}$ & $3024 / 0 / 220$ \\
Final $R$ indices [I $>2 \sigma(\mathrm{I})]$ & 0.986 \\
$R$ indices (all data) & $R_{1}=0.0321, w R_{2}=0.0628$ \\
Largest diff. peak and hole & $R_{1}=0.0495, w R_{2}=0.0658$ \\
\hline
\end{tabular}




\section{References}

1. Caroll, P. E. J. Am. Med. Assoc. 1966, 198, 267.

2. Schroeder, H. S.; Balassa, J. J. Am. J. Physiol. 1965, 209, 433.

3. Li, X. F.; Dong, J. T.; Wei, H. J.; Luo, X. M. Develop Biol. Chem. Biol. Phy. 1992, 19, 72.

4. Yang, J. R.; He, J. Q.; Zhang, G. X.; Mao, X. Q. Chin. Enviro. Sci. 1996, 16, 1000.

5. Clegg, W.; Cressey, J. T.; McCamley, A.; Straughan, B. P. Acta Crystallogr. Sect. C, 1995, 51, 234.

6. Rardin, R. L.; Tolman, W. B.; Lippard, S. J. New J. Chem. 1991, 15, 417.

7. Xiong, R. G.; Liu, C. M.; Zuo, J. L.; You, X. Z. Inorg. Chem. Commu. 1999, 2, 292.

8. Liu, C. M.; Xiong, R. G.; You, X. Z.; Chen, W.; Lo, K. M. J. Coord. Chem. 1998, 46, 211.

9. Xu, X. Y.; Wang, Z. L.; Luo, Q. H.; Shen, M. C.; Zhou, X. G.; Zhou, Z. Y. J. Coord. Chem. 1998, $43,281$.

10. Xiao, W.; Lu, Z. L.; Su, C. Y. J. Mol. Struct. 2000, 533, 91.

11. Hunter, R. H.; Haueisen, R. H.; Irving, A. Angew. Chem. Int. Ed. Engl. 1994, 33, 566.

12. Chesnut, D. J.; Kusnetzow, A.; Birge, R.; Zubieta, J. J. Chem. Soc., Dalton Trans. 2001, 2581.

13. Jian, F. F.; Wang, Z. X.; Bai, Z. P.; You, X. Z.; Chen, W. Trans. Met. Chem. 1999, 24, 589.

14. Jian, F. F.; Wang, Z. X.; Bai, Z. P.; You, X. Z.; Fun, H. K.; Chinnakali, K. J. Chem. Crystallogr. 1999, 24, 589.

15. CCDC 241966 contains the supplementary crystallographic data for this paper. These data can be obtained free of charge via www.ccdc.cam.ac.uk/conts/retrieving.html (or from the CCDC, 12 Union Road, Cambridge CB2 1EZ; fax +44 1223 336033; e-mail: deposit@ccdc.cam.ac.uk).

16. Sheldrick, G. M. SADABS, Program for Empirical Absorption Correction of Area Detector Data; University of Gottingen: Gottingen, Germany, 1996.

17. Sheldrick, G. M. SHELXTL V5.1 Software Reference Manual, Bruker AXS, Inc: Madison, Wisconsin, USA, 1997.

18. Wilson, A. J. C. International Tables for X-ray Crystallography, Vol. C; Kluwer Academic Publishers: Dordrecht, The Netherlands, 1992; Tables 6.1.1.4 (pp. 500-502) and 4.2.6.8 (pp. 219222), respectively.

Sample availability: Available from the authors.

C 2004 by MDPI (http://www.mdpi.org). Reproduction is permitted for noncommercial purposes. 